\title{
Structure of sea ice in McMurdo Sound, Antarctica
}

\author{
Stephen J. Jones, Brian T. Hill \\ Institute for Marine Dynamics, National Research Council of Canada, P.O. Box 12093, St John's, Nerefoundland A1B 3T5, Canada
}

\begin{abstract}
Sea-ice cores from 11 sites in McMurdo Sound, Antarctica, were collected in 1982 and their crystallography examined. All but one were first-year sea ice. The cores, approximately $2 \mathrm{~m}$ long, consisted typically of a thin layer of granular or snow ice (approximately $0.1 \mathrm{~m}$ ) followed by columnar-grained ice in the top metre and platelet ice in the bottom metre. Salinity and temperature measurements are reported. The columnar-grained ice usually had a strong preferred $c$-axis orientation in the horizontal plane and also showed a change in this preferred direction with depth in the ice. The mean $c$-axis orientation, however, usually aligned well with measured or implied currents in the Sound. The platelets were usually aligned with $c$ axis horizontal or close to horizontal, and did not exhibit as marked a preferred orientation as the columnar-grained ice.
\end{abstract}

\section{INTRODUCTION}

Between October and December 1982, one of the authors (S.J.J.) took part in a project to investigate the nature of the ocean currents and temperatures beneath the first-year sea ice of McMurdo Sound, Antarctica (McMurdo station: $77^{\circ} 52^{\prime} \mathrm{S}, 166^{\circ} 40^{\prime} \mathrm{E}$ ). Part of this project, described here, was a study of the sea ice itself. The oceanographic work has already been published (Lewis and Perkin, 1985) and the present results are those referred to in that paper as "private communication".

Previous studies of the sea ice in McMurdo Sound have been made by a number of workers. Paige (1966) studied the growth rate of the ice cover, the stratigraphy of the cores including observations of crystal platelets and their size, and found a preferred $c$-axis orientation in stressed, pressure-ridged ice. He also conducted ring-tensile strength measurements on the ice. Hendrickson and Rowland (1965) made about 300 ring-tensile tests on sea ice from the McMurdo area and correlated their results with brine volume. Gow and others $(1981,1982,1998)$ studied the $c$-axis alignment of first-year sea ice in McMurdo and found "strong-to-moderate $c$-axis alignments were observed at about $60 \%$ of the sampling sites". They also reported considerable sub-ice platelet growth. Crocker and Wadhams (1989) used an existing thermodynamic ice-growth model to predict the growth of fast ice in McMurdo Sound, and found significant discrepancies, which they attributed to the presence of sub-ice platelets and the formation of a snow-ice layer. Jeffries and others (1993) observed congelation and platelet ice in McMurdo Sound, studying the crystallography and the growth rates. Smith and others (1999) considered the platelet-ice growth in McMurdo Sound in detail, comparing published observations with hypothetical mechanisms of platelet growth.

The present paper presents observations similar to those of Jeffries and others (1993) and Gow and others (1998), but concentrates on the $c$-axis alignment within the cores and an apparent change in orientation with depth.

\section{APPARATUS AND METHOD}

Cores were retrieved from all sites using a standard "SIPRE" corer. After a few initial turns of the barrel, the corer was removed and a north-south orientation mark was scratched on the surface of the ice. This orientation was determined from a magnetic compass and/or time of day and/or local landmarks. Such cores are referred to as "oriented N/S". The thickness of the ice was approximately $2 \mathrm{~m}$, but the cores were usually retrieved in two or three pieces. They were immediately placed on a Styrofoam pad on the ice surface, and the different pieces matched at the breaks. The fracture surfaces could usually be joined together with confidence to recreate the entire core. Holes $4.8 \mathrm{~mm}$ in diameter were then drilled into the centre of some of the cores and a thermistor inserted to measure the temperature of the core along its length.

Cores were then either placed in $1 \mathrm{~m}$ long polyethylene tubes for transport back to McMurdo station to be used for crystallography studies, or immediately cut up and placed in labelled, watertight containers to be used later for conductivity and salinity measurements.

Transportation to and from McMurdo station was either by helicopter or by over-snow vehicle. The sites visited are shown as numbers $1-11$ in Figure 1.

Some preliminary crystallographic measurements were made in a cold laboratory at McMurdo station. However, the vast majority of the data presented here were collected after shipping the cores from McMurdo station to St John's, Newfoundland, via California and Ottawa. Considerable brine drainage probably occurred on the CaliforniaOttawa leg because some of the cores arrived in a rather 


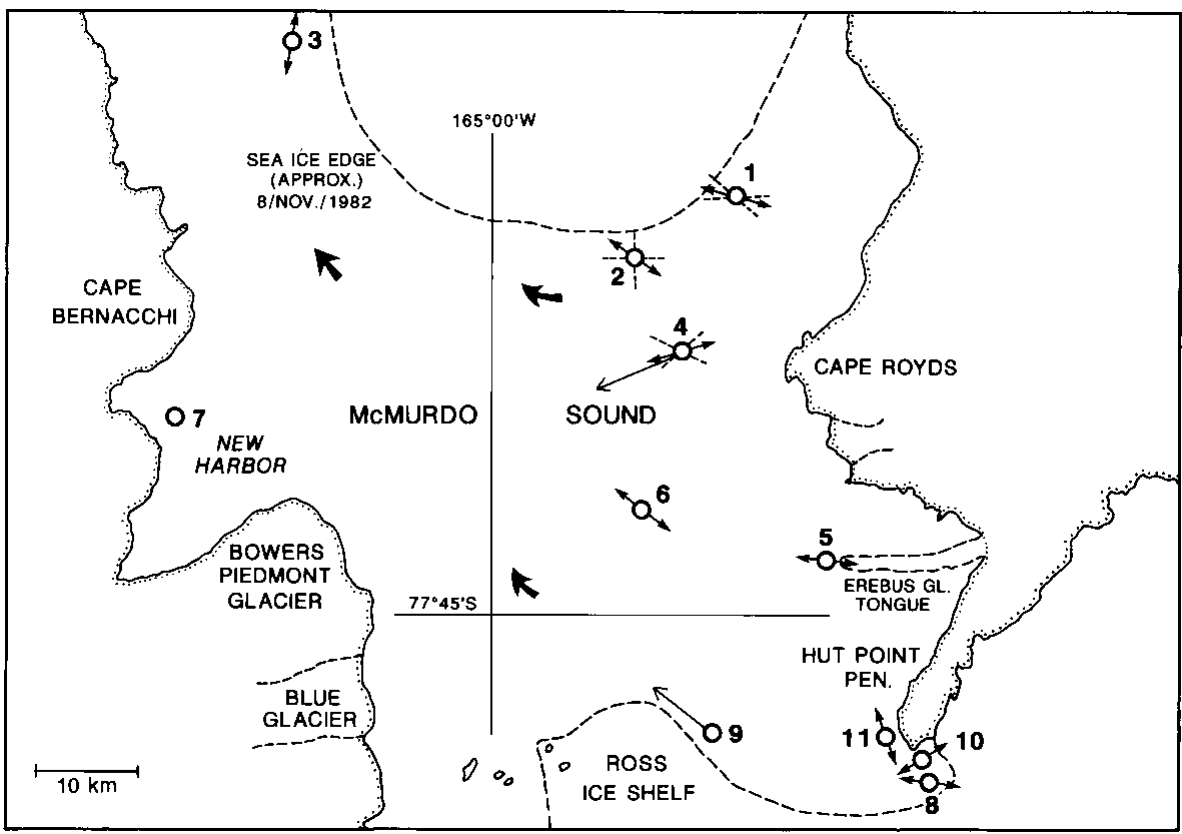

Fig. 1. Map of the area showing the sites visited, and the preferred c-axis direction in the core, given by the double-headed arrows. Where the $c$ axis rotated with depth, a range of orientations is shown by the dotted lines near the arrows. The large solid arrows indicate general water movement as described by Heath (1977); the long arrows at sites 4 and 9 show the mean current measured by Lewis and Perkin (1985) over a period of 1 month at $200 \mathrm{~m}$ depth.

\section{Temp., - ${ }^{\circ} \mathrm{C}$ or Salinity, ppt}

0

5

10

15

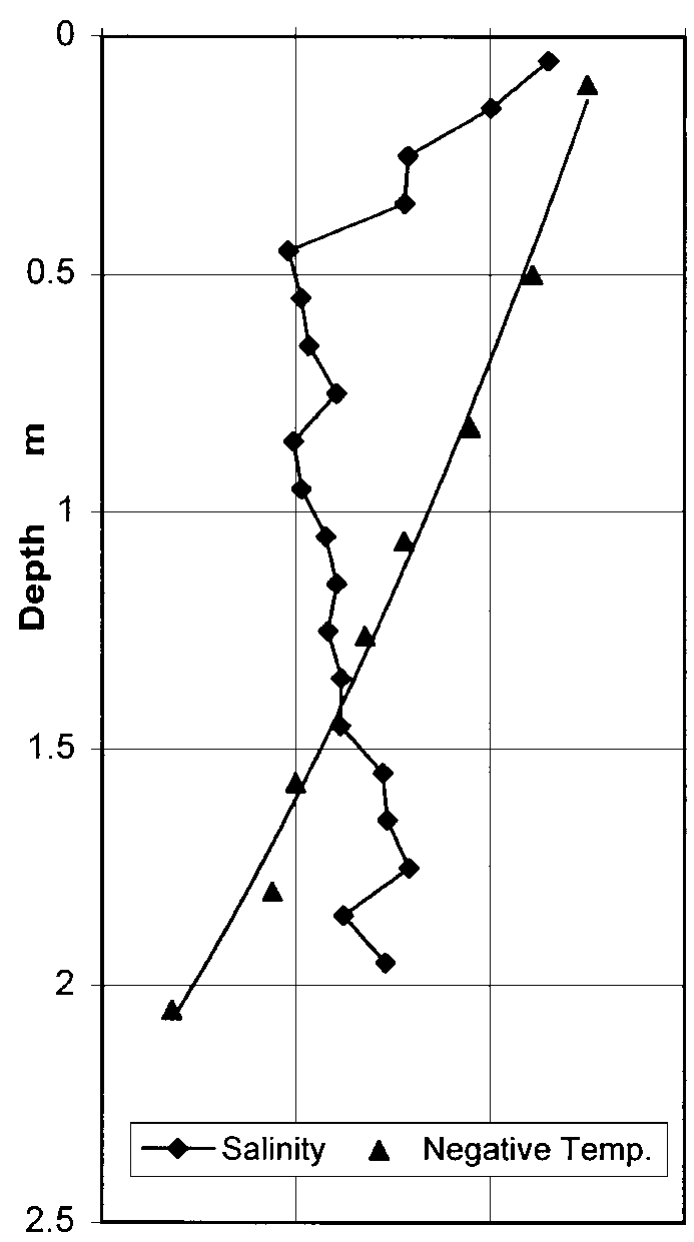

Fig. 2. Temperature and salinity measurements from site 2. wet condition. While this will undoubtedly have altered their mechanical properties, we do not believe it changed the crystal structure of the cores.

Salinity measurements were made at McMurdo station within a day or so of collection, after allowing the samples to melt and reach the room temperature of approximately $20^{\circ} \mathrm{C}$.

\section{RESULTS OF TEMPERATURE AND SALINITY MEASUREMENTS}

\section{Temperature measurements}

The measurements made at site 2 are shown in Figure 2 in which the in situ temperature is plotted against depth. All curves, from several sites, followed a similar trend from the surface air temperature to the melting point, $-1.9^{\circ} \mathrm{C}$, at the ice/ocean interface. Temperature measurements are accurate to $\pm 0.2^{\circ} \mathrm{C}$.

\section{Salinity measurements}

Salinity measurements were made on several cores, and results for site 2 are also shown in Figure 2. The general trend was a top layer of high salinity, $\approx 10 \mathrm{ppt}$, approximately $10-$ $20 \mathrm{~cm}$ thick, followed by the bulk of the core with a salinity of about 6 ppt. Sometimes there was a higher-salinity bottom layer (not seen in Fig. 2) which may have been due to contamination from the sea water when coring: when the corer broke through the ice, the bottom part of the core would be immersed in sea water. While efforts were made to "clean" this part of the core by wiping the outside surface, we may not have been entirely successful. The high-salinity top layer originated either as the natural rapid initial growth of ice from sea water, or possibly as a result of wind and waves breaking up an initial thin ice cover and splashing sea water onto the ice which would then be incorporated in the top layer when it re-formed. We do not believe this high-salinity top layer was due to contamination. 




Fig. 3. Structure of core from site 1 showing a marked preferred orientation that varied with depth, but with breaks in the core.

\section{GRYSTALLOGRAPHY OF THE CORES}

The bulk of the results obtained are concerned with the crystallography of the cores as determined from thin-section analysis. This was done using the standard techniques of a crossed-polaroid universal stage originally described by Langway (1958).

When retrieved, the bottom $10 \mathrm{~cm}$ or so of many of the cores showed obvious platelet ice (Wright and Priestley, 1922; Paige, 1966; Gow and others, 1981, 1982; Jeffries and others, 1993). These platelets were 1-3 mm thick and 10$50 \mathrm{~mm}$ in the other dimensions. The $c$-axis was perpendicular to the plate. From conversations with under-ice divers at McMurdo, this year was a "good" year for massive quantities of the loosely packed platelets, sometimes $3-4 \mathrm{~m}$ thick, attached to the underside of the growing ice cover. When a corer penetrates the bottom of the ice cover, however, any loosely attached platelets fall off, and only the few that are in the process of being incorporated into the ice cover proper are retrieved. As we will show in the detailed results to follow, this platelet growth appears to start after the ice reaches a thickness of approximately $1 \mathrm{~m}$.

\section{Site 1}

This site was situated close to the edge of the sea ice on 8 November 1982, as shown in Figure 1. The core was oriented $\mathrm{N} / \mathrm{S}$.

The structure of the core, determined by examining 23 horizontal or vertical thin sections under polarized light, is shown in Figure 3. This core shows the three main features present to a greater or lesser extent in all the cores, namely:

1. Fine-grained granular ice - but not very much of it. Usually random orientation but with one exception at site 6 . 


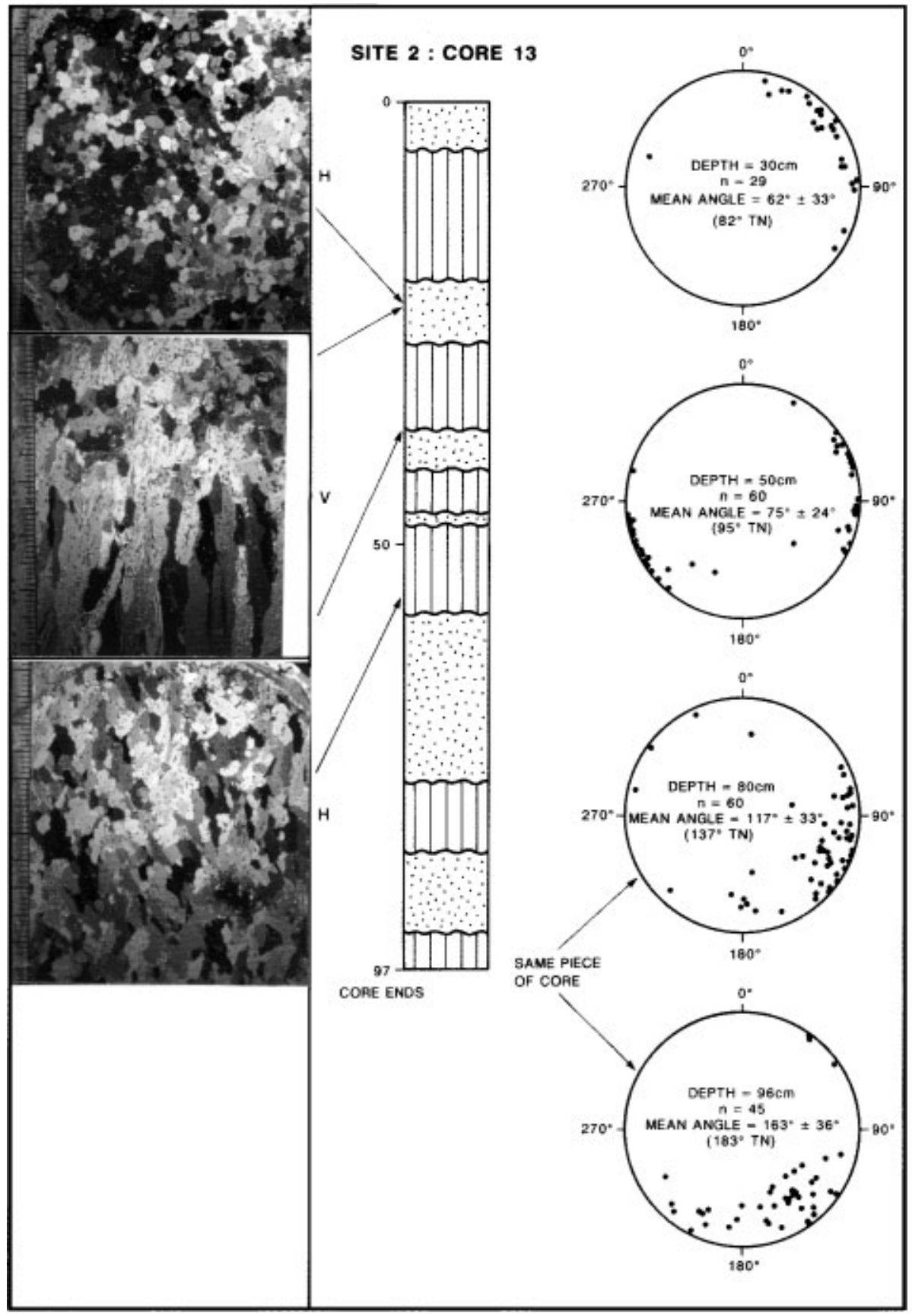

Fig. 4. Structure of core from site 2, showing columnar ice interspersed with fine-grained ice. A clear rotation of c-axis orientation with depth is found in an unbroken core at $0.8-0.96 \mathrm{~m}$ depth.

2. Congelation ice consisting of columnar crystals with horizontal $c$ axes, often with a strong $c$-axis alignment in a particular azimuth direction

3. Large platelets of ice in the bottom half of the cores, incorporated into the congelation ice, usually with $c$ axis in the horizontal plane but only weakly aligned in an azimuth direction.

Discussing site 1 in greater detail, Figure 3 shows that the granular ice extends to $0.22 \mathrm{~m}$ depth. There is then a sharp transition to columnar crystals with a very strong $c$-axis azimuth alignment of $97 \pm 21^{\circ}$ at $0.3 \mathrm{~m}$ depth, $87 \pm 16^{\circ}$ at $0.5 \mathrm{~m}$, and $131 \pm 12^{\circ}$ at $0.7 \mathrm{~m}$ (azimuths are corrected to true north). This apparent rotation of alignment with depth cannot be entirely trusted, because the core was broken at $0.56 \mathrm{~m}$ and may therefore have been misoriented when rejoined. However, as we will show later, rotation of $c$-axis orientation with depth did occur in cores that were unbroken. The columnar growth continues to $0.95 \mathrm{~m}$ depth, interspersed with thin layers of fine-grained ice, where there is a sudden transition to platelet ice. This is shown in the horizontal thin sections of Figure 3. These platelets become larger toward the bottom of the core.

Site 2

Only the top metre of the core was retrieved, due to time constraints on our helicopter crew, out of a total ice depth of $2.05 \mathrm{~m}$ and was oriented $\mathrm{N} / \mathrm{S}$.

Its structure is shown in Figure 4, in which it can be seen that columnar ice is repeatedly interspersed with finegrained granular ice. We do not believe this is the frazil ice reported by Ackley and others (1980) and Gow and others $(1982,1987)$ to be prominent in the Weddell Sea, because the crystals are more equiangular and larger $(1-2 \mathrm{~mm}$ 




Fig. 5. Structure of core from site 4, showing strong preferred orientation and identical crystals at depths of 0.19 and $0.29 \mathrm{~m}$.

diameter) than theirs. They often have a preferred $c$-axis vertical orientation in a large part of the thin sections, similar to that found by Gow and others (1987). This is the only core in which a significant amount of fine-grained ice appeared. Figure 4 shows a horizontal thin section of the fine-grained ice, and the fact that so many grains are in the "extinction" position indicates a preferred alignment in the vertical direction. The vertical thin section clearly shows the transition from fine-grained polycrystal to columnar at $0.25 \mathrm{~m}$ depth, and the horizontal section from $0.5 \mathrm{~m}$ depth shows columnar grains with preferred $c$-axis orientation. Figure 4 shows the orientation diagrams for depths of 0.3 , $0.5,0.8$ and $0.96 \mathrm{~m}$. They show a rotation in orientation from $82^{\circ} \mathrm{T}$ at $0.3 \mathrm{~m}$, to $183^{\circ}$ at $0.96 \mathrm{~m}$ assuming the breaks in the cores were matched correctly. The 0.8 and $0.96 \mathrm{~m}$ sections were, however, from the same piece of core, so there can be no doubt that the rotation of $46^{\circ}$ between these two sections is not due to mismatched core. There was no platelet ice in the top $0.95 \mathrm{~m}$; other cores show that such platelets do not normally form until 1-1.2 $\mathrm{m}$ depth.

\section{Site 3}

Site 3 was also near the sea-ice edge, but further west than sites 1 and 2. The core was oriented N/S. A thin, 70 mm, granular layer quickly gave way to columnar ice, initially with a random $c$-axis azimuth orientation, but at greater depths, around $0.6 \mathrm{~m}$, a strong preferred $c$-axis alignment was evident. At $0.75 \mathrm{~m}$ depth there was a sharp transition to platelet ice, which continues to the bottom of the core at $1.62 \mathrm{~m}$. Only at $0.6 \mathrm{~m}$ was a preferred azimuth direction evident. The samples from $0.75 \mathrm{~m}$ depth and greater were all platelet ice, and in each one the $c$-axis orientation was usually in a horizontal plane or about $20^{\circ}$ from the horizontal. There was no preferred direction within this plane. 


\section{Site 4}

The core was oriented N/S and details are shown in Figure 5. The two horizontal thin sections from 0.19 and $0.29 \mathrm{~m}$ depth not only showed a strong preferred orientation, but the similarity between the two sections was particularly striking, showing that columnar crystals can sometimes be identified $0.1 \mathrm{~m}$ apart in a core. The platelet-ice thin section from $1.39 \mathrm{~m}$ showed the more random nature of the $c$-axis orientation in such ice, usually in or close to a horizontal plane but random within the plane. Sometimes there were a significant number not even in a horizontal plane, as shown, for example, in Figure 5 at $1.62 \mathrm{~m}$ depth.

\section{Site 5}

A very strong $c$-axis alignment existed in the fine-grained columnar ice from $0.7-1.25 \mathrm{~m}$ depth. The orientations measured at $0.1 \mathrm{~m}, 105^{\circ} \mathrm{T}\left( \pm 23^{\circ}\right)$, and at $0.2 \mathrm{~m}, 89^{\circ} \mathrm{T}\left( \pm 13^{\circ}\right)$, were from the same piece of core, and show evidence of rotation of orientation with depth. The other orientations at 70 and $110 \mathrm{~cm}$ were very strongly aligned, but their compass orientation was not known because of breaks in the core that could not be matched.

\section{Site 6}

At this site there was considerably more granular ice and less columnar ice, and at $0.1-0.3 \mathrm{~m}$ depth this granular ice had a curious preferred $c$-axis alignment. The $c$ axes lay in a vertical plane, at about $130^{\circ} \mathrm{T}$. The columnar ice at $0.9 \mathrm{~m}$ had a weak alignment of $108^{\circ} \mathrm{T}$, in a horizontal plane. The transition to the platelet structure occurred at $0.95 \mathrm{~m}$ depth, although it was not as sharp a transition as in most cores. There was no strong alignment in an azimuth direction for the platelet ice.

\section{Site 7}

This was the only site where second-year ice was found, and the core, which had a total length of $2.97 \mathrm{~m}$, significantly longer than the others, was not oriented N/S. At the surface there was a $50 \mathrm{~mm}$ layer of granular ice with no brine pockets, followed by a $0.25 \mathrm{~m}$ layer with horizontal $c$ axis and some brine pockets, but fewer than in first-year ice. Then followed a layer at $0.3-0.4 \mathrm{~m}$ depth of large-grained, granular ice with no brine pockets and discoloured with organic matter. The remainder of the core was a mixture of columnar, granular and platelet ice.

\section{Site 8}

This site, close to the Ross Ice Shelf and furthest from the open sea, was, not surprisingly, the thickest first-year ice encountered at $2.3 \mathrm{~m}$. It was oriented $\mathrm{N} / \mathrm{S}$. The bulk of the top $1.26 \mathrm{~m}$ was columnar ice, changing abruptly at $1.26 \mathrm{~m}$ to platelet ice at a natural break in the core. The platelets extend to the bottom, becoming smaller with depth. The columnar grains at $1.1 \mathrm{~m}$ depth were aligned preferentially at $100^{\circ} \pm 20^{\circ} \mathrm{T}$, while the platelet ice at $1.3 \mathrm{~m}$ depth did not have such a clearly defined preferred orientation.

\section{Site 9}

Although a core was collected from here, the top $0.8 \mathrm{~m}$ was lost in transit. The remainder consisted of some columnar
Table 1. Thickness of sea ice and depth at which platelets start

\begin{tabular}{|c|c|c|c|c|c|c|c|c|c|c|}
\hline & \multicolumn{10}{|c|}{ Site } \\
\hline & 1 & 3 & 4 & 5 & 6 & 7 & 8 & 9 & 10 & 11 \\
\hline Total thickness (m) & 1.63 & 1.62 & 1.67 & 1.96 & 1.74 & $2.97^{*}$ & 2.30 & 2.20 & 2.00 & 2.07 \\
\hline $\begin{array}{l}\text { Depth platelets } \\
\text { start }(\mathrm{m})\end{array}$ & 0.95 & 0.75 & 0.95 & 1.30 & 0.95 & $1.6^{*}$ & 1.26 & 1.20 & 1.45 & 1.20 \\
\hline$\%$ platelets & 42 & 54 & 43 & 34 & 45 & 46 & 45 & 45 & 28 & 42 \\
\hline
\end{tabular}

* Multi-year ice.

ice with random $c$-axis horizontal orientation, but was composed mostly of coarse-grained granular ice and platelet ice.

\section{Site 10}

A very thin top layer of granular ice quickly changed to columnar ice with very marked $c$-axis azimuth alignment. The columnar ice continued until $1.45 \mathrm{~m}$, when a sudden change to a platelet structure occurred. The core was similar to that at site 8 .

\section{Site 11}

Again, as with sites 8 and 10 which were nearby, the core consisted of columnar ice which exhibited very strong $c$-axis alignment, and platelet ice. At $0.3-0.5 \mathrm{~m}$ depth the $c$ axis was aligned at $154^{\circ} \pm 14^{\circ} \mathrm{T}$. At $0.9-1.1 \mathrm{~m}$ the $c$-axis alignment rotated by almost $30^{\circ}$ from $55^{\circ} \pm 8^{\circ}$ at $90 \mathrm{~cm}$ depth to $82^{\circ} \pm 7^{\circ}$ at $110 \mathrm{~cm}$ depth. These changes are relative only; a break in the core meant that this piece could not be aligned N/S. However, the rotation occurred within one piece of core and is therefore an unambiguous example of $c$-axis rotation along a core.

\section{SUMMARY OF GRYSTALLOGRAPHY RESULTS}

Table 1 lists the total ice thickness at the various sites and the depth at which platelets started to be incorporated into the core. Site 2 is omitted because we retrieved only the top $0.96 \mathrm{~m}$. The data show that the platelet/congelation ice comprised approximately $40 \%$ of the cores. For sites 1, 3, 4 and 6, which are located some distance away from the Ross Ice Shelf or Erebus Glacier Tongue, the platelets started at $0.9 \pm 0.1 \mathrm{~m}$ depth, whereas at sites 5, 8, 9, 10 and 11 they started at $1.28 \pm 0.1 \mathrm{~m}$ depth. This suggests that the platelets formed at roughly the same time of year throughout the Sound since the sea-ice cover at sites 1, 3, 4 and 6 would have formed later in the year than at the other locations which are more sheltered. This is also shown by the thinner ice at sites 1,3,4 and 6 . This is consistent with Crocker and Wadhams (1989), who observed that the thickness of the platelet layer increased from early July (1986), when it first appeared, until mid-September, after which it remained fairly constant. Gow and others (1998) estimated that platelet-ice growth started in late August in 1980, but the platelets that year started at depths of about $1.75 \mathrm{~m}$.

\section{Alignment of $c$ axes}

Several cores showed a significant $c$-axis rotation with depth. At site 2, if all core breaks were matched correctly, a rotation of $100^{\circ}$ from $30 \mathrm{~cm}$ to $96 \mathrm{~cm}$ occurred. Sections from 80 and $96 \mathrm{~cm}$ were from the same piece of core and showed a rotation of $46^{\circ}$. 
Similarly, one piece of core from site 11 showed a $27^{\circ}$ rotation over only $0.2 \mathrm{~m}$ depth.

The preferred $c$-axis distribution is shown in Table 2 for all cases where the standard deviation was $<20^{\circ}$.

For those cores which were oriented N/S, a mean is calculated for all locations and this is plotted in Figure 1. For sites 1, 2 and 4 the range of angles found is also plotted in Figure 1; for the remaining sites the range was too small to plot.

Gow and others (1998) observed a similar change in orientation of about $20^{\circ}$ over a $0.6 \mathrm{~m}$ depth in 1980 at a site close to our site 11. They concluded that this was due to a change in current direction during the growth of the ice cover. No other workers have commented on a change in orientation with depth.

\section{GURRENT MEASUREMENTS}

Detailed conductivity-temperature-depth and current measurements were made at the same time as the present work by Lewis and Perkin (1985). The direction of their measured current at two sites over a period of 1 month, at $200 \mathrm{~m}$ depth, is shown in Figure 1. The magnitude of the measured current was always small, typically $20-30 \mathrm{~mm} \mathrm{~s}^{-1}$. The agreement between the measured direction of the current and the preferred $c$-axis orientations at the two sites is extremely good, although it must be remembered that the current was measured at $200 \mathrm{~m}$ depth. It is also interesting that in their paper, Lewis and Perkin (1985) show that at site 6 (their site 11) the current had two distinct directions during the course of the month, one at $270^{\circ}$ and one at $210^{\circ}$. At site 9 (their site 50) the current took on several directions in the course of the month.

This leads us to concur with other workers that the preferred $c$-axis orientation is essentially due to alignment with the current (Weeks and Gow, 1978, 1980; Langhorne, 1983; Langhorne and Robinson, 1986; Gow and others, 1998), and that the $c$-axis rotation with depth is a result of changing current directions.

\section{PLATELET IGE}

This project was not specifically intended to study the plateletice formation. Smith and others (1999) have discussed in detail the three main hypothetical mechanisms of platelet growth. First, water flowing from under the ice shelf becomes supercooled as it rises (Foldvik and Kvinge, 1974), and this could result in platelet ice nucleating in the water column and then floating up to the lower ice surface (Kipfstuhl, 1991). Second, the platelet ice could nucleate when the supercooled water reaches the sea ice, and third the platelet ice may grow directly from the sea ice (Paige, 1966; Gow and others, 1998). Our observations add little to this debate, but they do show that the platelet ice is widespread throughout the Sound. They also show that the platelet ice started at approximately $1.0 \mathrm{~m}$ depth in 1982, but varying in a manner that suggests that the platelets started at the same time of the year throughout the Sound. In 1980 there had been significantly less platelet ice, about $13 \%$ vs our $40 \%$, (Gow and others 1998), when it started to appear at depths of about $1.75 \mathrm{~m}$. In January 1990 (Jeffries and others 1993) there was a comparable amount to ours, but with greater variation in the Sound. Observations throughout the year are not available. Lewis and Perkin (1985), in work done at the same time as this paper, showed that there was considerable supercooling
Table 2. Preferred c-axis orientation for different sites as a function of depth

\begin{tabular}{|c|c|c|c|c|c|c|c|c|c|}
\hline $\begin{array}{c}\text { Depth } \\
\text { m }\end{array}$ & 1 & 2 & 3 & 4 & $\begin{array}{c}\text { Site } \\
5\end{array}$ & 6 & 8 & 10 & 11 \\
\hline 0.1 & & & & & $105^{\circ}$ & & & & \\
\hline $\begin{array}{l}0.2 \\
0.3\end{array}$ & $97^{\circ}$ & $82^{\circ}$ & & $\begin{array}{l}67^{\circ} \\
82^{\circ}\end{array}$ & $89^{\circ}$ & & & $40^{\circ}$ & $157^{\circ}$ \\
\hline 0.4 & & & & & & & & $32^{\circ}$ & $150^{\circ}$ \\
\hline 0.5 & $87^{\circ}$ & $95^{\circ}$ & $199^{\circ}$ & $115^{\circ}$ & & & & $65^{\circ}$ & $157^{\circ}$ \\
\hline 0.7 & $131^{\circ}$ & & & & & & & & \\
\hline 0.8 & & $137^{\circ}$ & & $53^{\circ}$ & & & & $77^{\circ}$ & \\
\hline 0.9 & & & & $49^{\circ}$ & & $108^{\circ}$ & & & $55^{\circ 1}$ \\
\hline $\begin{array}{l}1 \\
11\end{array}$ & & $183^{\circ}$ & & & & & $100^{\circ}$ & & $69^{\circ 1}$ \\
\hline $\begin{array}{l}1.1 \\
1.2\end{array}$ & & & & & & & & & $82^{\circ 1}$ \\
\hline $\begin{array}{l}1.2 \\
1.3\end{array}$ & & & & & & & & & \\
\hline 1.3 & & & & & & & $91^{\circ}$ & & \\
\hline Mean & $105^{\circ}$ & $124^{\circ}$ & $191^{\circ}$ & $73^{\circ}$ & $97^{\circ}$ & $108^{\circ}$ & $96^{\circ}$ & $54^{\circ}$ & $155^{\circ}$ \\
\hline
\end{tabular}

Notes: Orientation in degrees relative to true north; standard deviation $\pm 10^{\circ}$. Bold numbers are from unbroken core. Site 6 alignment was weak.

1 Part of unbroken core not aligned N/S.

present in the sea water beneath the ice in the Sound and that this acted as a heat sink for the growth of the platelet ice.

McMurdo Sound is an ideal location for the platelet ice because the formation of the platelets requires the nearby Ross Ice Shelf to discharge fresh water at depth (Lewis and Perkin, 1985). Once the sea-ice cover has formed, the water underneath is undisturbed because the currents and tides are not strong and the ice cover remains intact throughout the winter. The evidence for this is the absence of ridges in the ice, which would indicate the breaking-up and re-forming of the ice cover. The ice is an almost perfect example of uniform level ice.

\section{GONGLUSIONS}

The columnar-grained sea ice in McMurdo Sound had a marked $c$-axis horizontal azimuthal alignment, which we believe was a result of the direction of the mean water current at that location. The amount of granular ice present above the columnar ice was typically $<0.1 \mathrm{~m}$.

The $c$-axis alignment rotated markedly with depth at some locations, presumably due to changes in the water-current direction during growth. It is likely that the ice remained fast after being formed, because of the absence of ridges in the Sound.

Massive amounts of platelet ice formed at depths of approximately $1.0 \mathrm{~m}$, but varying with location in a manner that suggests that platelets had started to be incorporated into the ice sheet at the same time of year at all locations.

\section{ACKNOWLEDGEMENTS}

One of us (S.J.J.) is grateful to the National Hydrology Research Institute of Environment Canada for allowing him to take part in this work, to E. L. Lewis for inviting him, and to E. Sargent for considerable field support. The work formed part of project S-211-A (1982) funded by the U.S. National Science Foundation which also, together with the U.S. Navy and a contractor, provided excellent logistic 
support. W. F. Weeks provided valuable advice on field techniques before the trip, and A. J. Gow kindly commented on an early draft of the manuscript.

\section{REFERENCES}

Ackley, S. F., A. J. Gow, K. R. Buck and K. M. Golden. 1980. Sea ice studies in the Weddell Sea region aboard USCGC Polar Sea. Antarct. F. U.S., 15(5), 84-86.

Crocker, G. B. and P. Wadhams. 1989. Modelling Antarctic fast-ice growth. f. Glaciol., 35 (119), 3-8.

Foldvik, A. and T. Kvinge. 1974. Conditional instability of sea water at the freezing point. Deep-Sea Res., 21 (3), 169-174.

Gow, A. J., W. F. Weeks, J.W. Govoni and S. F. Ackley. 1981. Physical and structural characteristics of sea ice in McMurdo Sound, Antarctica. Antarct. 7. U.S., 16(5), 94-95.

Gow, A. J., S. F. Ackley, W. F. Weeks and J.W. Govoni. 1982. Physical and structural characteristics of Antarctic sea ice. Ann. Glaciol., 3, 113-117.

Gow, A. J., S. F. Ackley, K. R. Buck and K. M. Golden. 1987. Physical and structural characteristics of Weddell Sea pack ice. CRREL Rep. 87-14.

Gow, A. J., S. F. Ackley, J.W. Govoni and W. F. Weeks. 1998. Physical and structural properties of land-fast sea ice in McMurdo Sound, Antarctica. In Jeffries, M. O., ed. Antarctic sea ice: physical processes, interactions and variability. Washington, DC, American Geophysical Union, 355-374. (Antarctic Research Series 74.)

Heath, R. A. 1977. Circulation across the ice shelf edge in McMurdo Sound, Antarctica. In Dunbar, M.J., ed. Polar oceans. Montréal, Que., Arctic Institute of North America, 129-149.

Hendrickson, G. and R. Rowland. 1965. Strength studies on Antarctic sea ice. CRREL Tech. Rep. 157

Jeffries, M. O., W. F. Weeks, R. Shaw and K. Morris. 1993. Structural characteristics of congelation and platelet ice and their role in the development of Antarctic land-fast sea ice. f. Glaciol., 39(132), 223-238.

Kipfstuhl, J. 1991. Zur Entstehung von Unterwassereis und das Wachstum und die Energiebilanz des Meereises in der Atka Bucht, Antarktis. Ber. Polarforsch. 85.

Langhorne, P. J. 1983. Laboratory experiments on crystal orientation in $\mathrm{NaCl}$ ice. Ann. Glaciol., 4, 163-169.

Langhorne, P. J. and W. H. Robinson. 1986. Alignment of crystals in sea ice due to fluid motion. Cold Reg. Sci. Technol., 12(2), 197-214.

Langway, C. C., Jr. 1958. Ice fabrics and the universal stage. SIPRE Tech. Rep. 62.

Lewis, E. L. and R. G. Perkin. 1985. The winter oceanography of McMurdo Sound, Antarctica. In Jacobs, S. S., ed. Oceanology of the Antarctic continental shelf. Washington, DC, American Geophysical Union, 145-165. (Antarctic Research Series 43.

Paige, R. A. 1966. Crystallographic studies of sea ice in McMurdo Sound, Antartica. Port Hueneme, CA, U.S. Naval Civil Engineering Laboratory. (Technical Report R-494.)

Smith, I. J., P. J. Langhorne, H. J. Trodahl, T. G. Haskell and D. M. Cole. 1999. Platelet ice - the McMurdo Sound debate. In Shen, H. T., ed. Ice in surface waters. Rotterdam, A. A. Balkema, 829-834.

Weeks, W. F. and A. J. Gow. 1978. Preferred crystal orientations in the fast ice along the margins of the Arctic Ocean. 7. Geophys. Res., 83(C10), 5105-5121.

Weeks, W. F. and A. J. Gow. 1980. Crystal alignments in the fast ice of Arctic Alaska. 7. Geophys. Res., 85(C2), 1137-1146.

Wright, C. S. and R. E. Priestley. 1922. Glaciology. London, Harrison and Sons Ltd. British (Terra Nova) Antarctic Expedition 1910-13. 